\title{
Assessment of Human Herpes Virus 8 Infection among Breast Cancer Patients
}

\author{
Amira S. Mohamed ${ }^{1}$, Hanaa H.A. Gomaa ${ }^{1 *}$ and Fadia M. Attia ${ }^{2}$ \\ ${ }^{1}$ Department of Botany, Faculty of Science, Suez Canal University, Ismailia, Egypt \\ ${ }^{2}$ Department Clinical Pathology, Faculty of Medicine, Suez Canal University, Ismailia, Egypt \\ *Corresponding author
}

\section{A B S T R A C T}

\begin{tabular}{|c|c|}
\hline Keywords & 3) has recently emerged as causal factors of human \\
\hline $\begin{array}{l}\text { Breas } \\
\text { Huma } \\
\text { virus } \\
\text { HHV }\end{array}$ & $\begin{array}{l}\text { breast cancers. This study aims to assess the prevalence of HHV-8 DNA in women with } \\
\text { breast cancer. HHV-8 DNA was detected using Real-Time PCR in EDTA-treated whole } \\
\text { blood samples obtained from } 45 \text { breast cancer patients in Suez Canal University Hospital. } \\
\text { HHV-8 DNA was detected in } 13(28.8 \%) \text { patients. The prevalence of HHV-8 increased }\end{array}$ \\
\hline Arti & \\
\hline $\begin{array}{l}\text { Accepted: } \\
\text { 07 September } 2017 \\
\text { Available Online: } \\
10 \text { October } 2017\end{array}$ & $\begin{array}{l}\text { th lymph node (LN) metastasis compared lymph node-negative patients ( } 1 \text { out of } 33 ; 3 \\
\text { ). The prevalence of HHV-8 infection increased significantly with increasing tumor } \\
\text { ade and LN metastasis suggesting that HHV-8 may be a contributing factor to breast } \\
\text { incer progression and metastasis. }\end{array}$ \\
\hline
\end{tabular}

\section{Introduction}

Breast cancer is the most common cancer among females in Egypt, accounting for $37.7 \%$ of their total with 12,621 new cases in 2008. It is the leading cause of cancer-related deaths $[1,2]$.

Breast cancer carcinogenesis has been associated with the various risk factors including genetic predisposition, family history of breast cancer, dense breast tissue, lifestyle, hormonal contraception and treatment after menopause, and obesity.

These factors do not explain more than fifty percent of breast cancer cases [3, 4, 5, 6, 7]. Human Herpes virus $8(\mathrm{HHV}-8)$ is one of the recognized cancer-causing viruses in humans [8]. In 2010, HHV-8 was identified as a group 1 carcinogen by the International Agency for Research on Cancer (IARC) due to its specific public health threat related to its oncogenic potential [9].

Several factors make $\mathrm{HHV}-8$ a reasonable candidate for breast cancer [9], HHV-8 can infect and replicate in epithelial cells $[10,11]$, HHV-8 encodes viral interleukin 6 (vIL-6); Elevated expression of interleukin 6 was found to correlate with progression and metastasis of breast carcinoma [12, 13, 14], and HHV-8 was detected in breast cancer tissue by some investigators $[15,16]$. 
The main objectives of this study includes to assessment of HHV-8 DNA prevalence in women with breast cancer

\section{Study design}

This study was carried out on 45 female patients with breast cancer attending the oncology outpatient clinic of Suez Canal University Hospital in the period from May 2015 to February 2017 according to the principles of the Declaration of Helsinki, 2001. Their age ranged from 50-60 years with mean \pm SD $56.33 \pm 3.23$ years.

All patients had invasive ductal carcinoma classified into: 25 cases $(55.5 \%)$ were grade I, $14(31.1 \%)$ were grade II, and $6(13.3 \%)$ were grade III. $12(26.6 \%)$ patients had lymph node metastasis. Written informed consent was obtained from all participants enrolled in this study.

\section{Samples}

Five $\mathrm{ml}$ of venous blood samples were drawn under complete aseptic technique from all patients and collected into EDTA-treated tubes and were stored at $-20^{\circ} \mathrm{C}$ till the time of assay.

\section{DNA extraction}

DNA was extracted from EDTA-treated whole blood using QIAamp MinElute Virus kits according to manufacturer's instructions.

\section{DNA amplification}

Viral DNA was detected by Real Time PCR. Syber green method on $50 \mu \mathrm{l}$ of $2 \times$ Qiuantitect SYBR Green Master mix PCR kit (Qiagene, Germany), $1 \mu$ following primers (3'AGCCGAAAGGATTCCACCAT 5') and (3'TTCGTGTTGTCTACGTCCAG5'), $0.5 \mu \mathrm{l}$ nuclease free water and $2.5 \mu \mathrm{DNA}$ according to the manufacturer's instructions. The test was performed in 40 cycles, initiated by one cycle at $95{ }^{\circ} \mathrm{C}$ for $5 \mathrm{~min}$ for activating the Taq DNA polymerase followed by $95{ }^{\circ} \mathrm{C}, 10 \mathrm{~s} ; 60$ ${ }^{\circ} \mathrm{C}, 30 \mathrm{~s}$ and melting curve analysis proceeded by default parameter in Rotor-Gene instrument software. Statistical analyses were carried out using a program of Minitab 17. Pvalue $<0.05$ was considered significant.

\section{Results and Discussion}

The mean age of the HHV -8 positive group and HHV-8 negative group was 55.85 and 56.53 years respectively (Table 1). This difference was statistically insignificant.

Real-time PCR revealed that 13 out of 45 (28.8\%) blood samples of breast cancer cases were positive for HHV-8 DNA (Table 2 and Figure 1). Clinical and pathological characterization of patients regarding HHV-8 prevalence is described in Table 3 .

The results showed significant differences in the HHV-8 prevalence in breast cancer patients regarding the grade of tumor and lymph node status $(\mathrm{P}<0.05)$. The prevalence of HHV-8 DNA in breast cancer patients was higher $(6$ out of $6 ; 100 \%)$ in patients with tumor cancer grade III compared with HHV8DNA positivity in patients with tumor grade II (7 out of $14 ; 50 \%)$ and in patients with tumor grade I (HHV-8 DNA was absent). The proportion of $\mathrm{HHV}-8$ positive samples increased significantly with increasing tumor grade, from $0 \%$ for grade I, to $50 \%$ and $100 \%$ for grades II and III, respectively (Figures 2 and 3).

The results showed that HHV-8 DNA positivity in breast cancer patients was higher (12 out of $12 ; 100 \%$ ) in patients with lymph node metastasis compared with lymph nodenegative patients (1 out of $33 ; 3 \%$ ) (Figure 4). In the present study HHV-8 DNA was detected in $28.8 \%$ of breast cancer patients. 
These results are in agreement with findings from previous studies, which detected the presence of HHV-8 in breast cancer patients. The prevalence of antibodies against HHV -8 was 53 percent among 58 patients with breast cancer using ELISA [17]. HHV-8 was detected in 28 samples out of 62 tissue biopsies $(45.2 \%)$ of breast cancer patients using PCR and Southern hybridization. HHV8 was the most significantly associated virus with breast cancer [15].

HHV-8 DNA was detected in five women among 135 women diagnosed with breast cancer using PCR. The frequency of HHV-8 DNA was significantly higher in inflammatory breast cancer $(1.1 \%)$ than non- inflammatory breast cancer $(9.1 \%)$ tissues [16].

The variation of HHV-8 prevalence in breast cancer patients in different studies reflects different HHV-8 prevalence between different geographic regions and sub-populations [18] and differences in the sample site or the methodologies used for detecting the virus.

The present study showed a significant difference between HHV-8 positive and negative breast cancer groups regarding the grade of tumor and lymph node status but no significant difference was noticed between HHV-8 positive and negative breast cancer groups regarding age.

Fig.1 HHV-8 prevalence in breast cancer patients

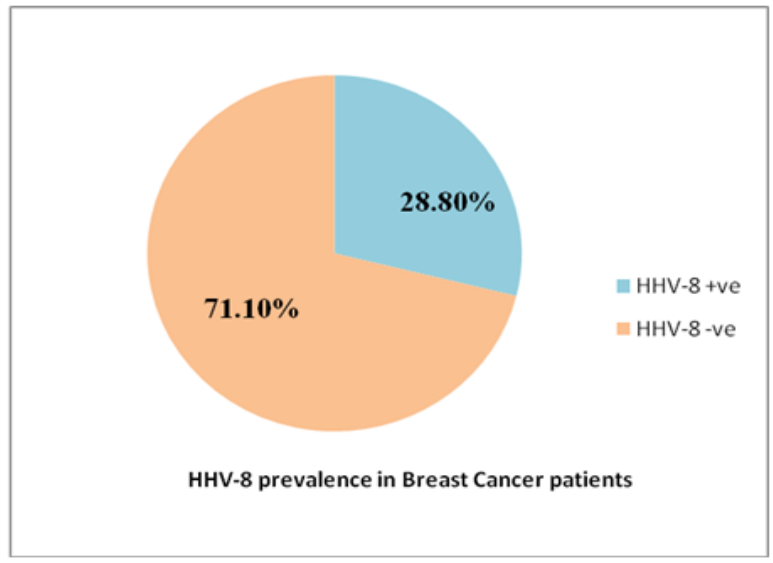

Fig.2 Showing correlation between tumor grade and HHV-8 prevalence

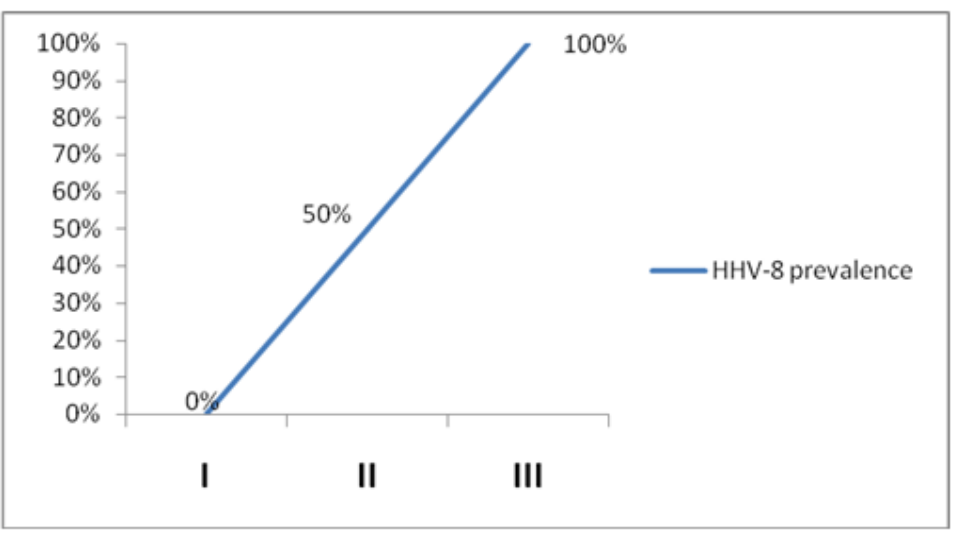


Fig.3 Prevalence of HHV-8 among breast cancer patients regarding to tumor grade

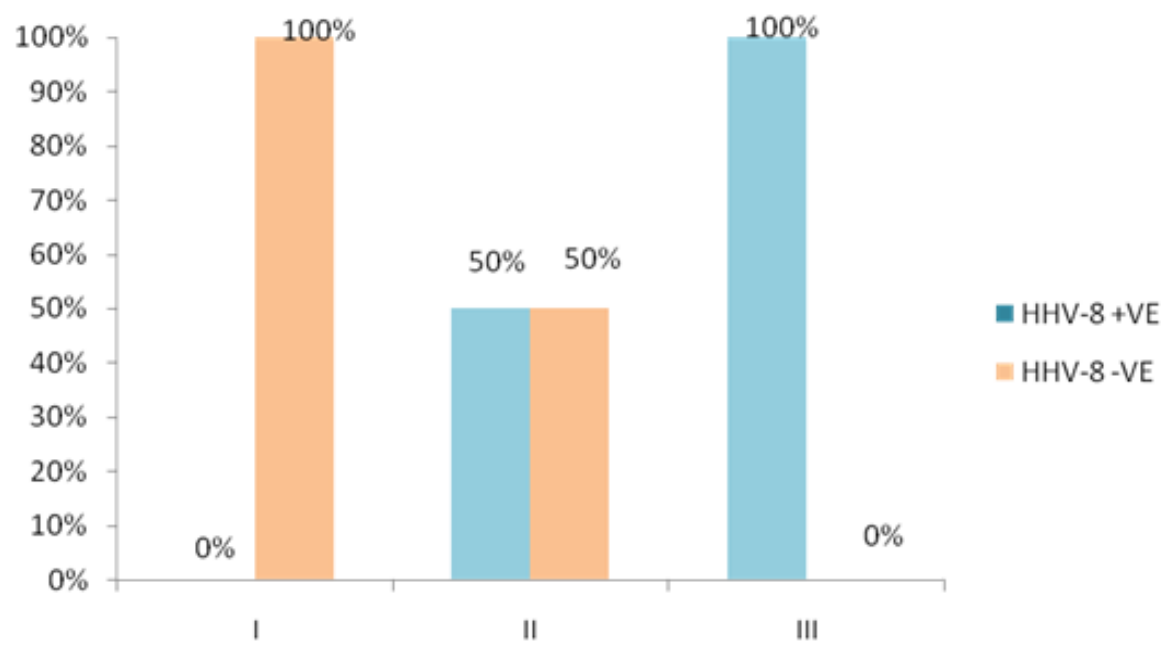

Fig.4 Prevalence of HHV-8 among breast cancer patients regarding to lymph node metastasis

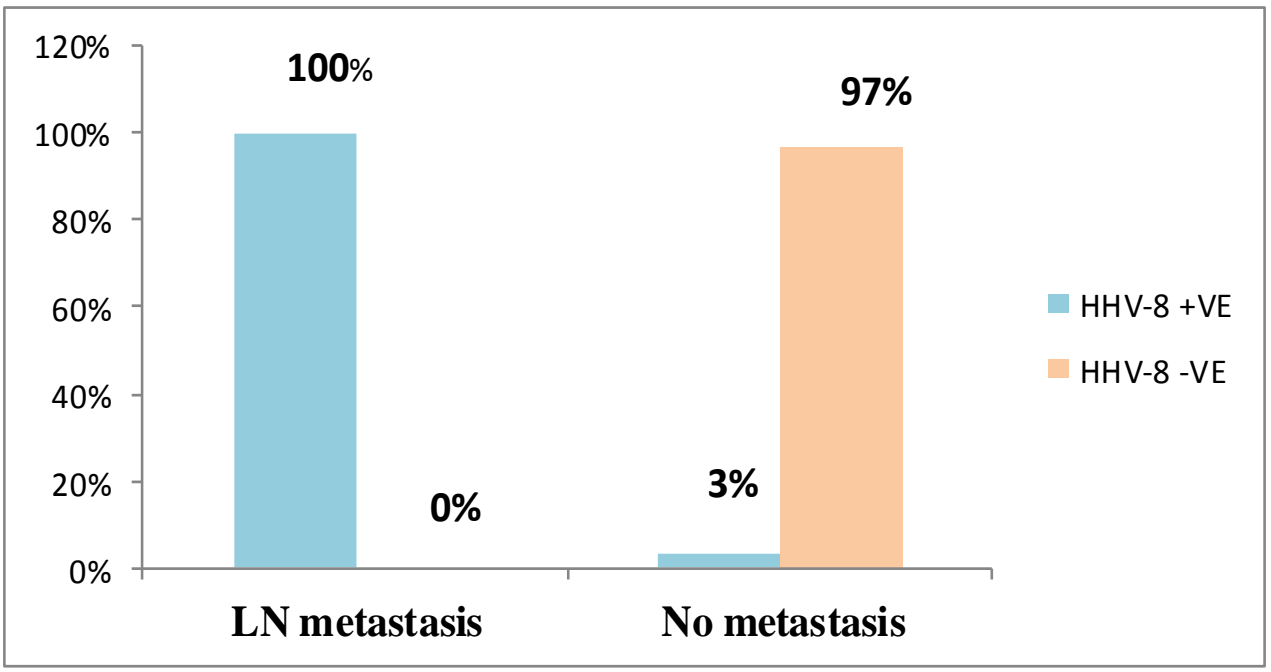

Table.1 Comparison of age mean in HHV-8 positive and negative breast cancer groups

\begin{tabular}{|l|l|l|l|l|l|l|}
\hline Groups & N & $\begin{array}{l}\text { Mean } \\
\text { years }\end{array}$ & $\begin{array}{l}\text { Stand. } \\
\text { deviation }\end{array}$ & mini & maxi & $\begin{array}{l}\text { T test } \\
\text { P value }\end{array}$ \\
\hline HHV-8 positive & 13 & 55.85 & 3.18 & 50 & 60 & 0.524 \\
\hline HHV-8 negative & 32 & 56.53 & 3.28 & 50 & 60 & \\
\hline
\end{tabular}

Table.2 Prevalence of human herpes virus (HHV-8) among breast cancer patients

\begin{tabular}{|l|l|l|l|}
\hline PCR results & Positive HHV-8 & HHV-8 Negative & Total \\
\hline Breast Cancer & $13(28.8 \%)$ & $32(71.1 \%)$ & 45 \\
\hline
\end{tabular}


Table.3 Comparison of clinicopathological features among HHV-8 positive and negative breast cancer patients

\begin{tabular}{|c|c|c|c|c|c|}
\hline \multirow{2}{*}{ Variables } & Total & $\begin{array}{c}\text { HHV- 8 } \\
\text { positive }\end{array}$ & $\begin{array}{c}\text { HHV-8 } \\
\text { negative }\end{array}$ & \multirow{2}{*}{ P value } \\
\hline \multirow{3}{*}{ Grade of tumor } & I & 25 & $0(0 \%)$ & $25(100 \%)$ & \multirow{2}{*}{0.001} \\
\cline { 2 - 5 } & II & 14 & $7(50 \%)$ & $7(50 \%)$ & \\
\cline { 2 - 5 } & III & 6 & $6(100 \%)$ & $0(0 \%)$ & \multirow{2}{*}{0.001} \\
\hline \multirow{2}{*}{ LN metastasis } & Yes & 12 & $12(100 \%)$ & $0(0 \%)$ & \\
\cline { 2 - 5 } & No & 33 & $1(3 \%)$ & $32(97 \%)$ & \\
\hline
\end{tabular}

In the present study, the proportion of HHV-8 prevalence increased significantly with increasing tumor grade, from $0 \%$ for grade I, to $50 \%$ and $100 \%$ for grades II and III, respectively.

Furthermore, it was found that HHV-8 prevalence was significantly associated with lymph node metastasis, where HHV-8 DNA was detected in all patients with lymph node metastasis (12/12), while HHV-8 DNA was detected in only one among 33 Lymph nodenegative patients.

From these results, HHV-8 may play a role in breast cancer carcinogenesis but it seems unlikely to have an etiological role in the genesis of breast cancer as HHV-8 is only detected in some breast cancer patients. The virus might contribute to tumor progression and metastasis of the disease. HHV-8 may alter the behavior of already transformed cells so that they acquire a more aggressive manner.

HHV-8 encodes a viral homolog of interleukin 6. Interleukin 6 induces increased motility, cell-cell and cell-substrate dyshesion and epithelial-to-mesenchymal transformation in breast cancer cells [19]. During the process of epithelial-mesenchymal transition (EMT), epithelial cancer cells acquire molecular alternations that cause loss of epithelial features and gain of mesenchymal phenotype.
This transformation enhances cancer cell migration, invasion, and metastasis $[20,21]$.

Elevated IL-6 levels was found to correlate with advanced breast tumor stage, tumor progression, metastasis and increased number of metastatic sites in breast cancer patients $[12,13,14]$. Moreover, HHV-8 is linked to a number of malignancies thought to be driven by interleukin-6 (IL-6). Thus, viral IL-6 is involved in HHV-8 carcinogenesis [22, 23, 24]. This may explain the increasing HHV-8 prevalence in advanced breast tumor grade and breast cancer patients with $\mathrm{LN}$ metastasis as found in this study.

The studies concerning HHV-8 in breast cancer are few, while there are several studies for breast cancer and Epstein-Barr virus (EBV), a $\gamma$ herpes virus closely related to HHV8 [25]. These studies make EBV a potential contributor to the breast cancer. Consequently, this makes HHV-8 a putative contributor to breast cancer, especially both viruses can infect epithelial cells and B cells and cause malignancies such as lymphoma and are members of the same subfamily $\gamma$ herpes virus.

Human herpes virus 8 (HHV-8) is associated with B cell and endothelial tumors. But recently HHV-8 has been detected in prostate epithelial cells and was implicated in prostate cancer in several studies [26, 27]. HHV-8 was 
found to cause epithelial cell transformation and to promote epithelial cell growth in prostate cancer [28]. Therefore, HHV-8 may be able to infect epithelial mammary cells and may cause mammary cells transformation. HHV-8 has been indeed detected in breast cancer tissue by some investigators $[15,16]$.

HHV-8 is known to have oncogenic potential and possess various possible mechanisms for immortalizing and transforming mammary cells. HHV-8 can inhibit cell apoptosis and induce cell proliferation, cell survival, and tumor angiogenesis, modulate immune surveillance and can overlap with cellular signaling pathways those already implicated in breast cancer. For example, HHV-8 activates the Jak/STAT3 pathway believed to implicated in breast cancers [29]. In addition, its viral genome contains several genes that are homologous to proto-oncogenes, cellular genes capable of inducing malignant tumors [30]. These factors make $\mathrm{HHV}-8$ a reasonable candidate for breast cancer deserves to be studied. If proven, this finding would lead to better diagnosis, prevention, and treatment of the breast cancers.

In conclusion, this study demonstrated the presence of HHV-8 DNA in considerable breast cancer patients in Ismailia suggesting that HHV-8 might have a role in the pathogenesis of breast cancer. The prevalence of HHV-8 increased significantly with increasing tumor grade and $\mathrm{LN}$ metastasis. These results imply that $\mathrm{HHV}-8$ may be a contributing factor to breast cancer progression and metastasis.

\section{References}

1.Globocan, 2008. Cancer Incidence and Mortality Worldwide: IARC Cancer base no. 10. International Agency for Research on Cancer, v1.2 http://globocan.iarc.fr/ 2008.
2. The National Cancer Registry Program of Egypt NCRPE). 2013. Reports and Statistics: Aswan, Damietta \& ElMinia http://www.cancerregistry. gov.eg/reports.aspx

3. Madigan, M.P. Ziegler, R.G. and Benichou, J. 1995. Proportion of breast cancer cases in the United States explained by well-established risk factors. J Natl Cancer Inst 87:1681-5.

4. Mezzetti, M. L. Vecchia, C. Decarli, A. Boyle, P. Talamini, R. and Franceschi, S. 1998. Population attributable risk for breast cancer: diet, nutrition, and physical exercise. $\mathbf{J}$ Natl Cancer Inst 389-94.11.

5. Martin, A.M. and Weber, B.L. 2000. Genetic and hormonal risk factors in breast cancer. J Natl Cancer Inst 92:1126-35.

6. Hulka, B.S. and Moorman, P.G. 2001. Breast cancer: hormones and other risk factors. Maturitas 38:103-13.

7. Dumitrescu, R.G. and Cotarla, I. 2005. Understanding breast cancer riskwhere do we stand in 2005? J Cell Mol Med 9:208-221.

8. Boshoff, C. and Weiss, R. 2002. "Aidsrelated malignancies". Nature Reviews Cancer. 2 5.373-382.

9. IARC 2012. Kaposi's sarcoma herpesvirus IARC Monogr Eval Carcinog Risks Hum, 100B: 169-214.

10. Cerimele F., Curreli F., Ely E., FriedmanKien A. E., Cesarman E., Flore O. 2001. Kaposi's sarcoma associated herpesvirus can productively infect primary human keratinocytes and alter their growth properties. J. Virol., 75: 2435-2443.

11.Akula, S. M. Naranatt, P. P. Walia, N. S. Wang, F.-Z. Fegley, B., and Chandran, B. 2003. Kaposi's Sarcoma-Associated Herpesvirus Human Herpesvirus 8) Infection of Human Fibroblast Cells Occurs 
through Endocytosis. Journal of Virology, 7714), 7978-7990.

12. Kozlowski, L. Zakrzewska, I. Tokajuk, P. and Wojtukiewicz, M.Z. 2003. Concentration of interleukin-6 IL-6), interleukin-8 IL-8) and interleukin-10 IL-10) in blood serum of breast cancer patients. RoczAkad Med Bialymst48: 82-4.

13. Salgado, R. Junius, S. Benoy, I. Van Dam, P. Vermeulen, P. Van Marck, E. and et. al. 2003. Circulating interleukin-6 predicts survival in patients with metastatic breast cancer. IntJCancer 103: 642-6.

14. Ahmed, O. I. Adel, A. M. Diab, D. R. and Gobran, N. S. 2006. Prognostic value of serum level of interleukin- 6 and interleukin-8 in metastatic breast cancer patients. Egypt J. Immunol., 13, 61-68.

15. Tsai, J.H. Tsai, C.H. Cheng, M.H. Lin, S.J. $\mathrm{Xu}$, F.L. and Yang, C.C. 2005. Association of viral factors with nonfamilial breast cancer in Taiwan by comparison with non-cancerous fibroadenoma and thyroid tumor tissues. J. Med. Virol. 75, 276-281.

16. El-Shinawi, M. Mohamed, H.T. AbdelFattah, H.H. and et. al. 2016. Ann Surg Oncol 23: 494. doi:10.1245/s10434-015-4888-2

17. Newton, R. Ziegler, J. Bourboulia, D. Casabonne, D. Beral, V. Mbidde, E. Carpenter, L. Reeves, G. Parkin, D.M. Wabinga, H. Mbulaiteye, S. Jaffe, H. Weiss, R. and Boshoff, C.2003. The sero-epidemiology of Kaposi's sarcoma-associated herpesvirus $\mathrm{KSHV} / \mathrm{HHV}-8$ ) in adults with cancer in Uganda. Int. J. Cancer.103, 226232.

18. Dukers N.T. and Rezza G. 2003. Human herpesvirus 8 epidemiology: what we do and what we do not know, AIDS 17 .1717-1730.
19. Sehgal, P.B. 2010. Interleukin-6 induces increased motility cell-cell and cellsubstrate dyshesion and epithelial-tomesenchymal transformation in breast cancer cells. Oncogene doi: 10.1038/onc.2010.4.

20. Blick, T. Hugo, H. Widodo, E. Waltham, M. Pinto, C. Mani, S.A. Weinberg, R.A. Neve, R.M. Lenburg, M. E. and Thompson, E.W. J. 2010. Mammary Gland Biol Neoplasia. Jun 152.23552.

21. Bill, R. Christofori, G. and Febs, L. 2015. The relevance of EMT in breast cancer metastasis: Correlation or causality? 58914.1577-87.

22.Staskus KA, Sun R, Miller G, Racz P, Jaslowski A, Metroka C, Brett-Smith H, Haase AT .1999. Cellular tropism and viral interleukin-6 expression distinguish human herpesvirus 8 involvement in Kaposi's sarcoma, primary effusion lymphoma, and multicentric Castleman's disease. J Virol. 1999 May 735.4181-7.

23.Oksenhendler E, Carcelain G, Aoki Y, Boulanger E, Maillard A, Clauvel JP, Agbalika F.2000. High levels of human herpesvirus 8 viral load, human interleukin-6, interleukin-10, and $\mathrm{C}$ reactive protein correlate with exacerbation of multicentric castleman disease in HIVinfectedpatients. Blood.966.2069-73 24. Aoki Y, Tosato G, Fonville TW, Pittaluga S 2001. Serum viral interleukin-6 in AIDSrelated multicentric Castleman disease. Blood 97: 2526-2527.

25.Lawson, J. S. and Heng Benjamin, H. 2010. Viruses and Breast Cancer Cancers. 2, 752-772.

26. Hayes RB, Pottern LM, Strickler HD, et al. 2000. Sexual behavior, STDs, and risks for prostate cancer. Br J Cancer 82:718-25. 
27.Linda J. Hoffman, Clareann H. Bunker, Philip E. Pellett, Donald L. Trump, Alan L. Patrick, Sheila C. Dollard, Hillary A. Keenan, Frank J. Jenkins 2004. Elevated Seroprevalence of Human Herpesvirus 8 among Men with Prostate Cancer. J Infect Dis 189 1. 15-20. doi: 10.1086/380568

28.Justin G. Mygatt, Adit Singhal, Gauthaman Sukumar, Clifton L. Dalgard, and Johnan A.R. Kaleeba. 2013. Oncogenic Herpesvirus HHV-8 Promotes AndrogenIndependent Prostate Cancer Growth. CAN-12-
4196

29.Banerjee K and Resa H. 2016. Constitutive activation of STAT3 in breast cancer cells: Int. J. Cancer: 138, 2570-2578

30.Russo JJ, Bohenzky RA, Chien MC, Chen J, Yan M, Maddalena D, Parry JP, Peruzzi D, Edelman IS, Chang Y, et al.1996. Nucleotide sequence of the Kaposi sarcoma-associated herpesvirus HHV8) Proc Natl Acad Sci U S A. 93:14862-14867. doi: 10.1073/pnas.93.25.14862

\section{How to cite this article:}

Amira S. Mohamed, Hanaa H.A. Gomaa and Fadia M. Attia. 2017. Assessment of Human Herpes Virus 8 Infection among Breast Cancer Patients. Int.J.Curr.Microbiol.App.Sci. 6(10): 661-668. doi: https://doi.org/10.20546/ijcmas.2017.610.081 